\title{
Environmental enrichment on the behavior and welfare of cockatiels (Nymphicus hollandicus)
}

[Enriquecimento ambiental no comportamento e no bem-estar de calopsitas (Nymphicus hollandicus)]

\author{
V.D.L. Assis ${ }^{1}$, T.S.G. Carvalho' ${ }^{2}$, V.M. Pereira ${ }^{3}$, R.T.F. Freitas ${ }^{2}$, C.E.P. Saad ${ }^{2}$, \\ A.C. $\operatorname{Costa}^{2}$, A.A.A. Silva ${ }^{4}$ \\ ${ }^{1}$ Universidade Federal de Goiás - Goiânia, GO \\ ${ }^{2}$ Universidade Federal de Lavras - Lavras, MG \\ ${ }^{3}$ Universidade Federal de Minas Gerais - Belo Horizonte, MG \\ ${ }^{4}$ Centro Universitário de Lavras - Lavras, MG
}

\begin{abstract}
This study evaluated the influence of physical environmental enrichment on the behavior of cockatiels (Nymphicus hollandicus). Eighteen birds, nine males and nine females, were monitored in environments enriched with wooden sticks and bead rings and in non-enriched environments, in a completely randomized design. Behavioral categories were grouped into locomotion, maintenance, rest, feed, undesirable activities, and interaction with environmental enrichment. Data were analyzed using descriptive analysis of behaviors to produce the ethogram and percentage comparison of frequency values for behavior analysis. Environmental enrichment positively influenced behavioral categories and some behavioral activities of birds.
\end{abstract}

Keywords: ethogram, parrot, stress, wild animal

\section{RESUMO}

Objetivou-se, com o presente trabalho, avaliar a influência do enriquecimento ambiental físico sobre o comportamento de calopsitas (Nymphicus hollandicus). Foram monitoradas 18 aves, sendo nove machos e nove fêmeas, em ambientes enriquecidos com tocos de madeira e argola de miçangas e sem enriquecimento ambiental. O delineamento foi inteiramente ao acaso. As categorias comportamentais foram agrupadas em locomoção, manutenção, repouso, alimentação, atividades indesejáveis e interação com o enriquecimento ambiental. Os dados foram examinados por meio da análise descritiva dos comportamentos para elaboração do etograma e comparação percentual das frequências observadas para análise dos comportamentos. Foi observada influência positiva do enriquecimento ambiental sobre as categorias comportamentais e algumas atividades comportamentais das aves.

Palavras-chave: animal selvagem, etograma, estresse, psitacídeos

\section{INTRODUCTION}

Characteristic features of parrots (Psittaciformes) include a strong, curved bill and thick fleshy tongue with the upper jaw curved over the lower one, adapted for a seed and fruit-based diet. Members of this order include macaws, parrots, parakeets, cockatoos, and cockatiels (Nymphicus hollandicus). The Cockatiel was described by
Scottish writer and naturalist Robert Kerr in 1793 as Psittacus Hollandicus and was subsequently moved to its own genus, Nymphicus, by Wagler in 1832 . The bird became well known in England in 1864, and around 1884 there were several European breeders.

Cockatiel breeding requires no special authorization, as the Ordinance No. 93 of the Brazilian Institute of Environment and

Recebido em 11 de setembro de 2015

Aceito em 7 de janeiro de 2016

E-mail: nessinhadany@yahoo.com.br 
Renewable Natural Resources of June 71998 considers these birds as pets (Ibama, 1998), thus enabling captive breeding.

A captive environment is mostly a structure where animals rarely face challenges when compared to the natural environment, which can cause them problems. Environmental enrichment techniques have been used as an alternative to reduce such concerns. Cubas et al. (2006) described environmental enrichment as an example of promoting captive animal welfare, as it provides opportunities to maintain motor skills and exploratory, predatory, and other nearnatural behaviors, thus improving psychological and physiological welfare and health conditions. However, introducing any form of environmental enrichment requires knowing animal behavior. To expand knowledge beyond practice, we can use ethograms for each species. Del-Claro (2004) defined ethograms as tabular representations to classify and quantify a species' behaviors, composing a properly quantified list of behavioral acts which may be described when necessary.

This study evaluated the influence of environmental enrichment on the behavior of captive cockatiels (Nymphicus hollandicus) by comparing the frequency of behavioral categories and bird activities.

\section{MATERIAL AND METHODS}

The experiment was conducted at the Division of Wildlife, Department of Animal Science (DZO), Federal University of Lavras (UFLA), located in southern Minas Gerais at a $900 \mathrm{~m}$ altitude. This study had the approval of the ethics committee in the use of animals, under protocol 013/13.

The study observed eighteen cockatiels, nine females and nine males at an average age of ten months. Birds were identified by open bands around the left paw in females and right paw in males for easy differentiation.

Each bird was housed in a wire cage of $85 \times 40 \times 45 \mathrm{~cm}$ (length, depth, height) comprising three wood perches, two feeding bowls (plastic and ceramic), and a ceramic water bowl placed on the bottom. Cages were placed side by side in two shelves of $10 \mathrm{~m}$ each in a 12-meter masonry shed covered with asbestos roof tiles. Temperature and humidity were measured by a thermo hygrometer.

Birds received 12 hours of artificial light (40 W lamps) controlled by timer Elcon TE 30. The behavioral analysis took place during the day, from $6 \mathrm{am}$ to $6 \mathrm{pm}$. Feed and water were provided ad libitum, and feed comprised a seed mixture of $50 \%$ millet, $30 \%$ birdseed, $15 \%$ oat, $5 \%$ sunflower, and commercial parrot feed. Cage management was performed once a day from $8 \mathrm{am}$ to $10 \mathrm{am}$, and afterwards the birds remained alone.

The trial took place from March - May 2013. In March the birds were observed to produce the ethogram. In April and May the experiment began by introducing environmental enrichment. After a seven-day adjustment, we began the observation phase.

Environmental enrichment tools were:

- Wood sticks $3 \mathrm{~cm}$ long and $2 \mathrm{~cm}$ wide with a hole, so that birds could easily catch them with their beaks;

- Iron rings with $14 \mathrm{~cm}$ circumference partially covered with beads, so that birds could move them around the ring.

Cockatiels (Nymphicus hollandicus) were observed in the experimental area using the ad libitum technique. According to Castro (2010), this method consists of non-systematic records in which the observer tries to note all visible and relevant activities.

Observations lasted seven days from 8am - 11am and $12: 30 \mathrm{pm}-4: 30 \mathrm{pm}$, amounting to 49 hours. The ethogram for evaluating bird behavior was based on both previous bird observations and adapted ethograms by Prestes (2000), Pimenta et al. (2009), Sgarbiero (2009), Silva et al. (2010), and Andrade and Azevedo (2011). Activities were grouped into behavioral categories defined as locomotion, maintenance, rest, feeding, undesirable activities, and interaction with enrichment tools.

We found 15 types of behavior in the species under study, listed on Table 1. 
Table 1. Behavioral acts recorded on observation of cockatiels (Nymphicus hollandicus) with abbreviations and description of each behavior

\begin{tabular}{ccl}
\hline Behavioral Categories & Abbreviation & \multicolumn{1}{c}{ Description } \\
\hline \multirow{3}{*}{ Locomotion } & DP & Moving laterally on the perch \\
& AT & Walking on the cage screen \\
& A & Walking on the cage floor \\
\hline \multirow{2}{*}{ Maintenance } & LP & Preening \\
& SP & Shaking the plumage \\
\hline \multirow{2}{*}{ Rest } & R & Resting over the belly, head backwards rested on the \\
& RP & back or under the wing, or eyes closed \\
& PT & Standing still on the cage screen \\
Feeding & PCH & Standing still on the cage floor \\
\hline \multirow{2}{*}{ Undesirable Activities } & BA & Drinking water \\
& C & Climbing food bowls or eating \\
\hline Interaction with & RPA & Biting the perch \\
enrichment tools & RG & Biting food bowls \\
\hline
\end{tabular}

Based on previous observations and adapted from Prestes (2000), Soares et al. (2009); Sgarbiero (2009), Silva (2010), and Andrade (2011).

Data was collected by recording each cage for 12 uninterrupted hours from $6 \mathrm{am}-6 \mathrm{pm}$ during three consecutive days, totaling 36-hours of footage per period.

We used the all-occurrence sampling technique, which according to Roll (2006) allows for observing an animal group by recording all occurrences of a given category in a previously determined behavior. Images were recorded by three video cameras (Camera Color $8 \mathrm{~mm}$ CCD $1 / 3$ Infrared ST1230) placed on tripods $1.20 \mathrm{~cm}$ distant from the cages and connected to a Dvr Stand Alone 4 Channels 120 Frames Lux Vision Vga 3g. Images were transmitted to an LG monitor c17lc-0 for analysis. Footage material was monitored every ten minutes while recording for collecting data series for behavioral analysis: $6 \mathrm{xz}$ observations/hour/cage, 72 observations/day/cage, 216 observations/cage/ period, 648 observations/cage during the experimental time. The total 11,664 observations were recorded on spreadsheets (Attachments) based on the behavioral categories as indicated in the ethogram.
The experiment used a completely random design in treatment rotation, so that each bird received all three treatments. At each enrichment change, the birds underwent a 7-day adaption period. Data were subjected to descriptive analysis of behaviors for making the ethogram and to percentage comparison of frequency values for behavioral analysis.

\section{RESULTS AND DISCUSSION}

Figure 1 shows the percentages of behavioral categories shown by the animals during the evaluation period. Observation frequency of behavioral categories differed between treatments.

Birds in cages without environmental enrichment moved around more frequently than the ones in the enriched environment. No abnormal behavior was recorded in this study. Locomotion is very important for assessing bird activity and excessive behavioral activities, as excess and repeatability of certain behaviors may indicate stereotyped or abnormal behavior. 


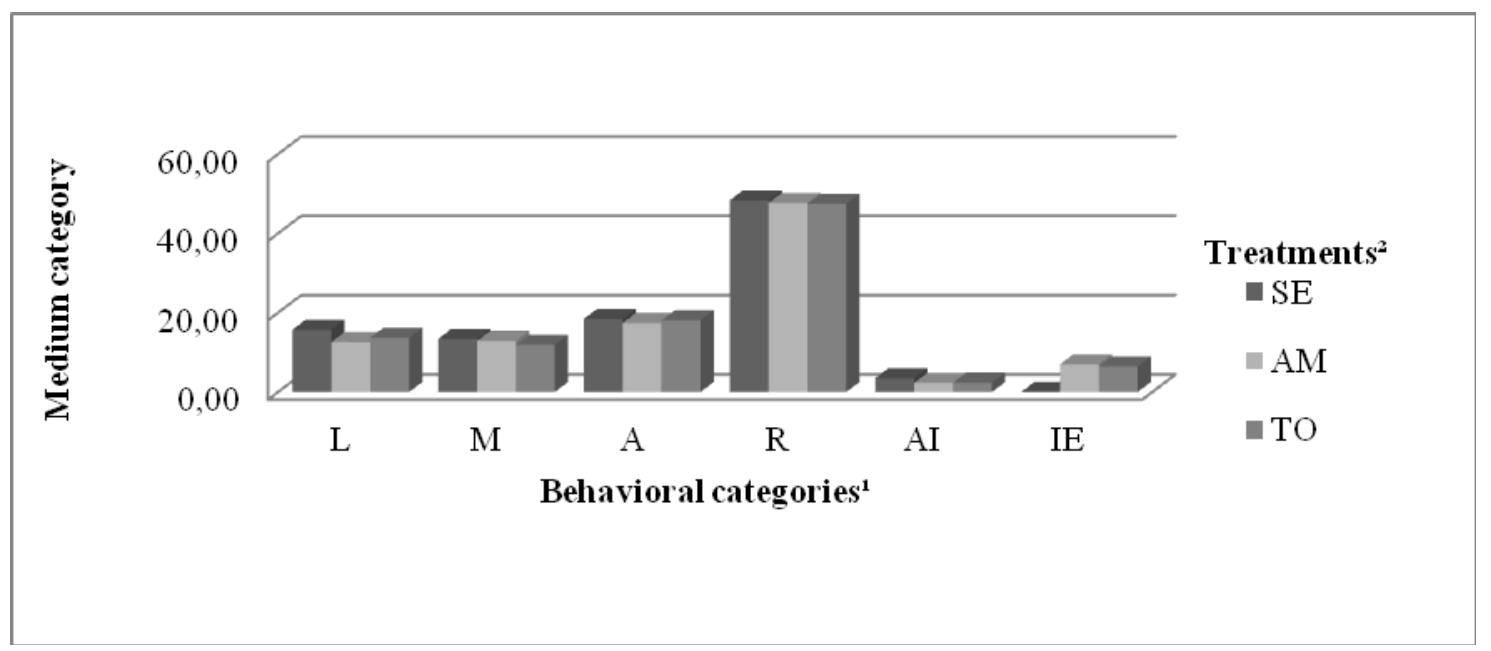

Figure 1. Percentage of behavioral categories in adult cockatiels (Nymphicus hollandicus) in three conditions of environmental enrichment

${ }^{1}$ L - Locomotion; M - Maintenance; A - Feeding; R - Rest; AI - Undesirable activities; IE- Interaction with enrichment tools. ${ }^{2}$ SE- No enrichment; AM- Bead rings; TO - Wood sticks.

Cockatiels spent more time preening feathers when cages were not enriched. However, this increased frequency did not lead to any exaggerated behavior. This result corroborates with Santos et al. (2011), who reported reduced preening in macaws housed in enriched environment.

Parrots spend most of their time preening feathers, lubricating and protecting them with uropygial gland oil. However, this behavior increases when the captive environment becomes boring, and exaggerated care can cause selfmutilation. Abnormal behaviors, such as stereotypies, self-mutilation, feather pecking, or excessively aggressive behavior indicate that the animal is under low welfare conditions (Broom and Molento, 2004).

We found a higher frequency of feeding in birds housed in cages without environmental enrichment. However, it is not possible to affirm that environmental enrichment negatively or positively affected the birds, as feed consumption was not measured during the evaluation period.
Birds in cages with environmental enrichment had decreased idleness in relation with birds without enrichment. This result corroborates with Soares et al. (2009) and Santos et al. (2011), who evaluated the influence of environmental enrichment on macaw behavior and found decreased bird idleness in cages with physical and feeding enrichment.

Environmental enrichment had a positive effect on the behavior of cockatiels, reducing the frequency of undesirable activities when bead rings and wooden sticks enriched the cages. In this study, birds interacted with both types of tools. These activities are good examples of promoting captive animal welfare, as they provide opportunities to maintain motor skills and exploratory, predatory, and other nearnatural behaviors, thus improving psychological and physiological welfare and health conditions (Cubas et al., 2006).

Frequency of birds moving laterally on the perch was higher with ring beads (AM) $(35.15 \%)$ and wooden sticks (TO) $(37.75 \%)$ in the cages (Figure 2). 


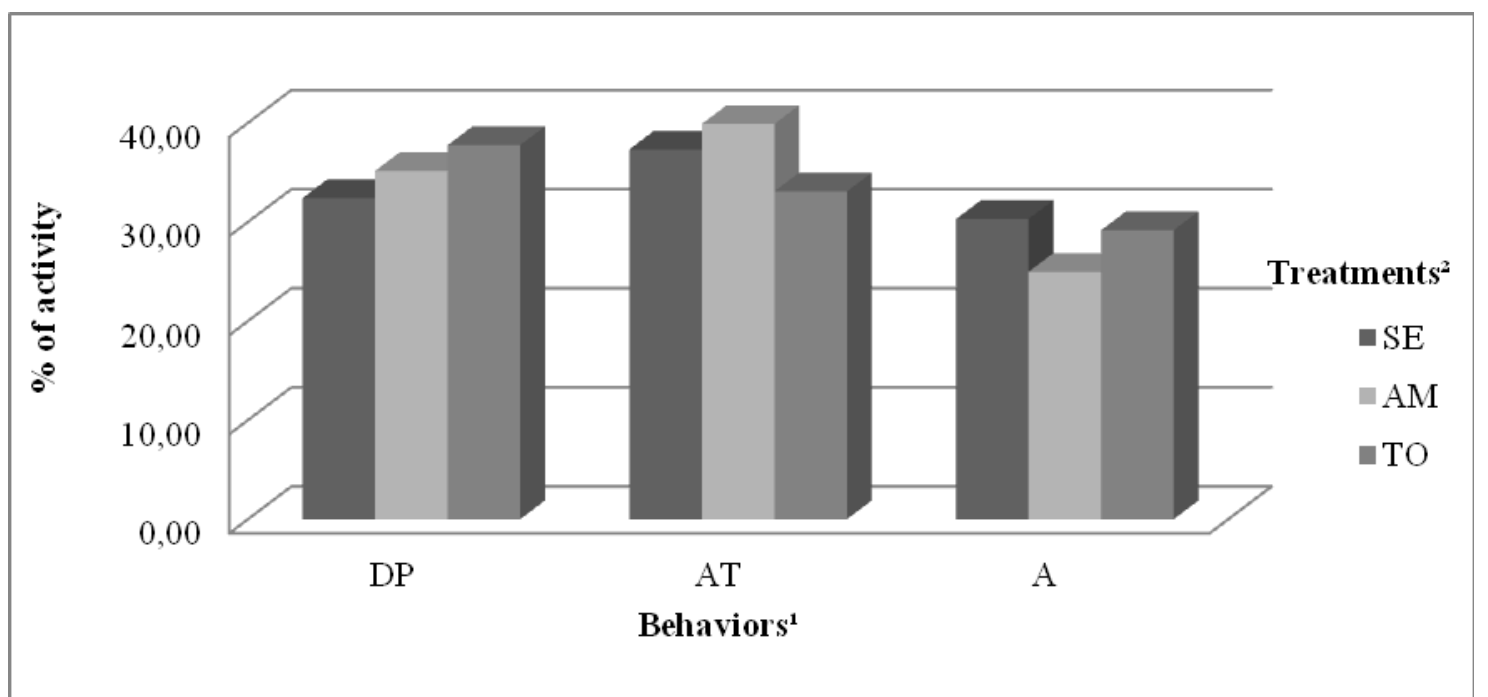

Figure 2. Mean frequency of behavioral activities in the category "locomotion" of adult cockatiels (Nymphicus hollandicus) in three conditions of environmental enrichment ${ }^{1}$ DP- Moving on the perch, AT- Walking on the cage screen, A- Walking on the cage floor. ${ }^{2} \mathrm{SE}-$ No enrichment, AM - Bead rings, TO - Wooden sticks.

Walking on the cage screen (AT) was more frequent in environments enriched with ring beads (AM) $(39.89 \%)$ than with wooden sticks (TO) $(33.08 \%)$. Walking on the floor was more frequent in cages with wooden sticks $(29.17 \%)$ than with ring beads (24.96\%). According to Andrade and Azevedo (2011), the behaviors "moving on the perch" and "moving on the cage screen" decreased with environmental enrichment.

Birds preened feathers (LP) more frequently $(91.84 \%)$ and shook the plumage (SP) less frequently $(8.16 \%)$ when there was no environmental enrichment available (Figure 3).

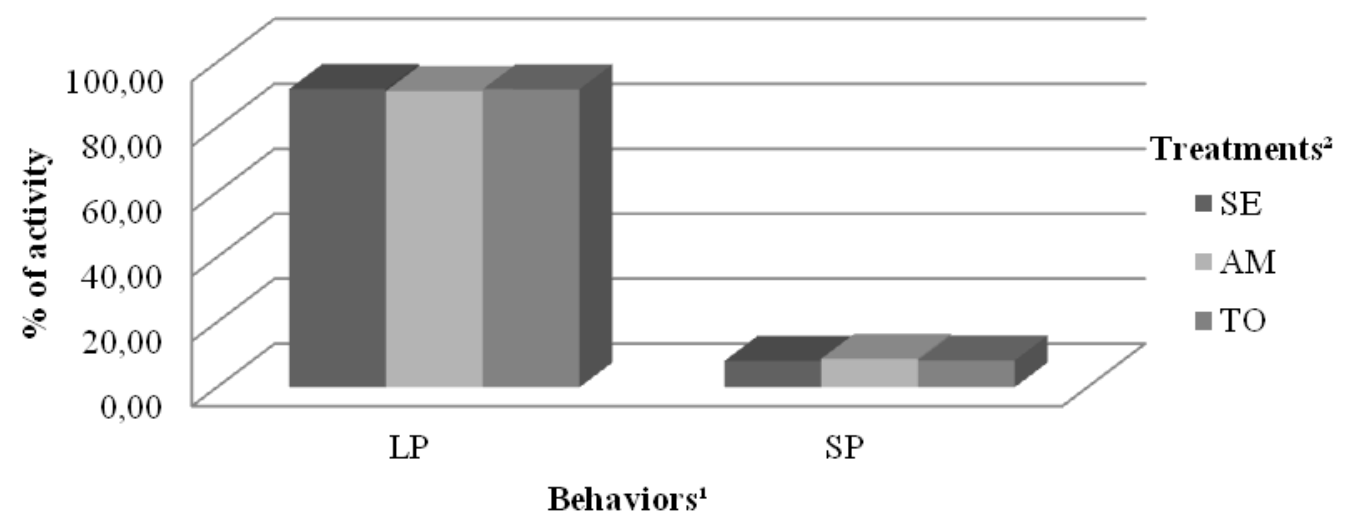

Figure 3. Mean frequency of behavioral activities in the category "maintenance" of adult cockatiels (Nymphicus hollandicus) under three conditions of environmental enrichment.

${ }^{1}$ LP - Preening feathers, SP - Shaking the plumage, ${ }^{2}$ SE - No enrichment. AM - Bead rings, TO - Wooden sticks. 
According to Andrade and Azevedo (2011), frequency of shaking the plumage is very high during the enrichment phase, as bird interaction is intense. Prestes (2000) suggests that the species (Amazona pretrei) of parrot family (Psittaciformes) such as cockatiels, scratches its own body mostly for relaxation and tranquility.
However, the behavior "preening feathers" was lower during the enrichment phase.

Environmental enrichment did not reduce the mean frequency of idleness in the evaluation of the behavioral activities "lying on belly" (R) and "resting on the perch" (RP) (Figure 4).

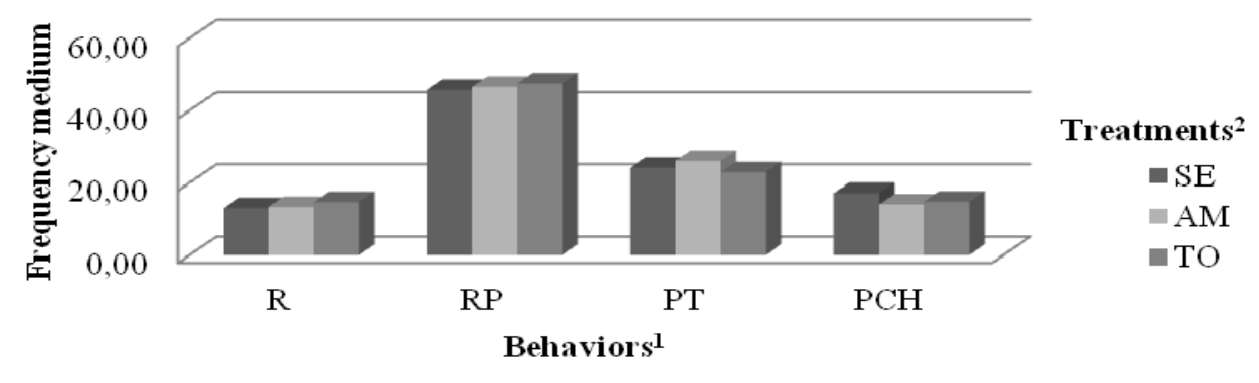

Figure 4. Mean frequency of behavioral activities in the category "rest" of adult cockatiels (Nymphicus hollandicus) in three conditions of environmental enrichment.

${ }^{1} \mathrm{R}$ - Lying on belly; RP - Resting on the perch, PCH - Standing on the cage floor, PT- Standing on the cage screen. ${ }^{2} \mathrm{SE}$ - No enrichment AM - Bead rings, TO - Wooden sticks.

However, birds stood still on the screen (PT) less in cages with wooden sticks (TO) $(22.92 \%)$ than in cages with bead rings (AM) or no enrichment (SE). The mean frequency of "standing on the cage floor" (PCH) reduced with bead rings (AM) $(14.06 \%)$ and wooden sticks $(14.84 \%)$.

Parrots in general are very active, curious birds (Gorman, 2010), thus captive ones need stimuli to prevent them from becoming too idle and bored. However, information on most species of parrots is limited, and captivity management can be challenging. Thus, daily observation of birds is very important to understand their behavior. (Allgayer and Cziulik, 2007). In the behavioral category "rest", it is clear that environmental enrichment can reduce idleness in some activities.

Bead rings (AM) and wooden sticks (TO) increased the frequency of behavioral activity "drinking water" (BA), (4.53\%) and (3.30\%) respectively (Figure 5).

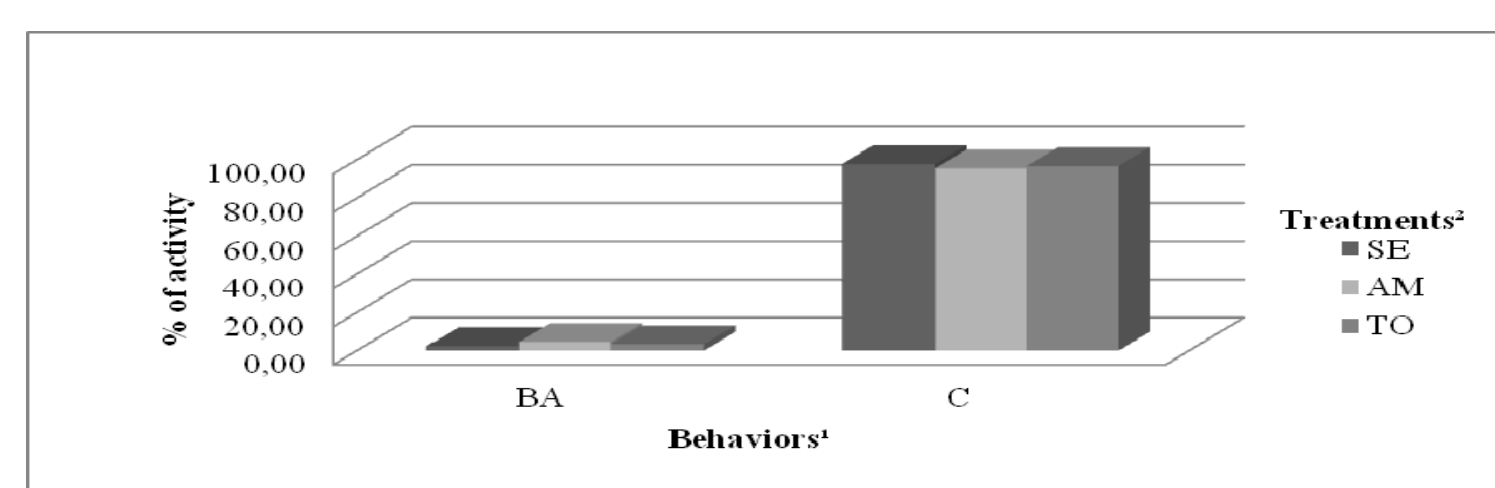

Figure 5. Mean frequency of behavioral activities in category "feeding" of adult cockatiels (Nymphicus hollandicus) in three conditions of environmental enrichment.

${ }^{1}$ BA-Drinking water, C- Climbing food bowls or eating. ${ }^{2} \mathrm{SE}$ - No enrichment, AM - Bead rings; TO Wooden sticks. 
Frequency of feeding was higher in birds in cages without environmental enrichment $(97.72 \%)$ than with enrichment.

Andrade and Azevedo (2011) reported that birds in cages without environmental enrichment increased water consumption and reduced dietary intake. Reduced consumption was explained by the greater interest of birds for enrichment items than for the feed available.

Undesirable activities "biting the perch" (RPO) and "biting the cage" (RG) were more frequent in birds in cages without environmental enrichment, (1.74\%) (RPO) and (64.34\%) (RG), showing that environmental enrichment could reduce such behaviors (Figure 6).

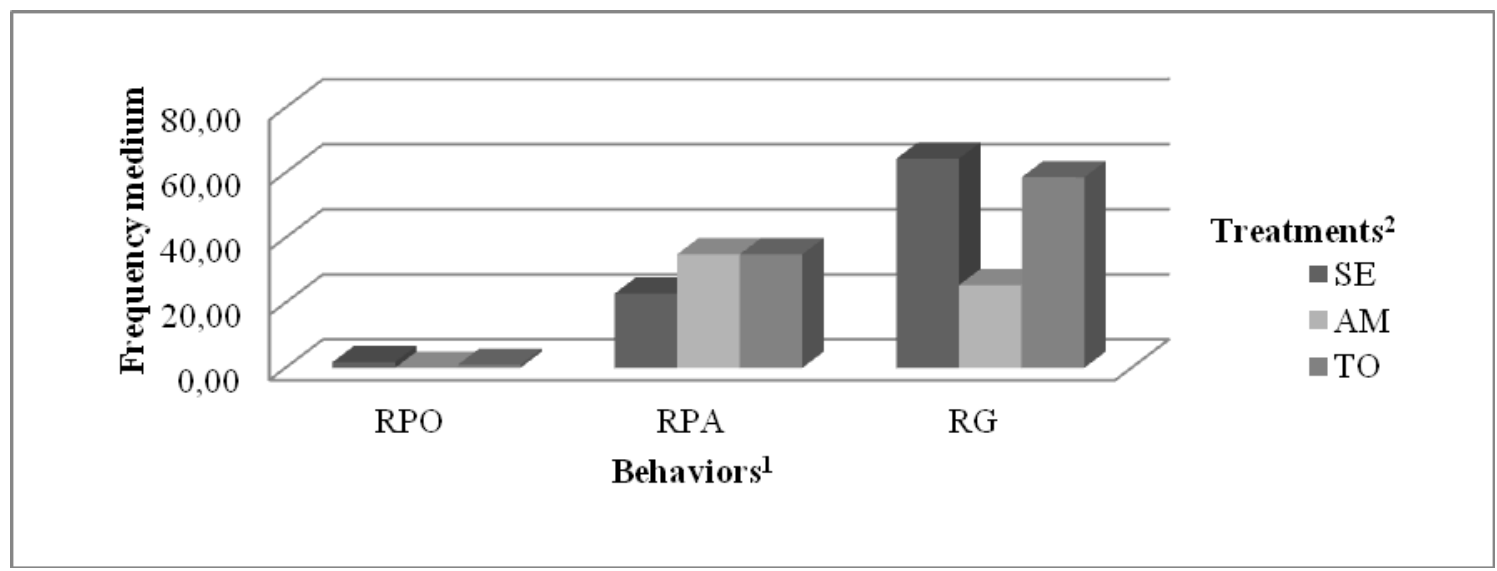

Figure 6. Mean frequency of behavioral category "undesirable activities" of adult cockatiels (Nymphicus hollandicus) in three conditions of environmental enrichment.

${ }^{1}$ RPO - Biting the perch, RPA - Biting food bowls, RG - Biting the cage. ${ }^{2}$ SE - No enrichment, AM- Bead rings, TO - Wooden sticks.

Biting the cage ( $R G$ ) was reduced by introducing environmental enrichment (bead rings - AM and wooden sticks - TO), and this behavior was less frequent when birds received bead rings (AM) $(25.43 \%)$. Bead rings (AM) and wooden sticks (TO) did not positively affected reduction in "biting food bowls" (RPA), showing that birds did not interact with enrichment tools enough to reduce this behavior (Figure 6).

When the environment is not enriched, captive parrots tend to bite everything around, which is a common habit in both nature and captivity. Biting is their way to wear the beak down to avoid abnormal growth, apart from being an activity to occupy time and reduce boredom. Typical behavioral mismatches are common in these species when observed in captive environments (Meehan et al., 2004). In this study we characterized undesirable behaviors as those that lead to nursery losses, as parrots cause destruction in facilities. The behaviors "pecking the perch" (BP), "pecking the screen" (BT), "walking from one side to the other" (PAC) and "pecking the wire" (BAR) are deemed abnormal behaviors (Young 2003).

Mean frequency showed that birds had greater interaction with bead rings than with wooden sticks (Figure 7).

This preference may have been due to wide color variation in bead rings in relation to wooden sticks. Turek (1963) cited by Kim et al. (2009) reported the preference of European birds for more colorful plants. Arruda et al. (2008) evaluated the influence of fruit color on bird preference and found they prefer bright-colored fruits to white ones. 


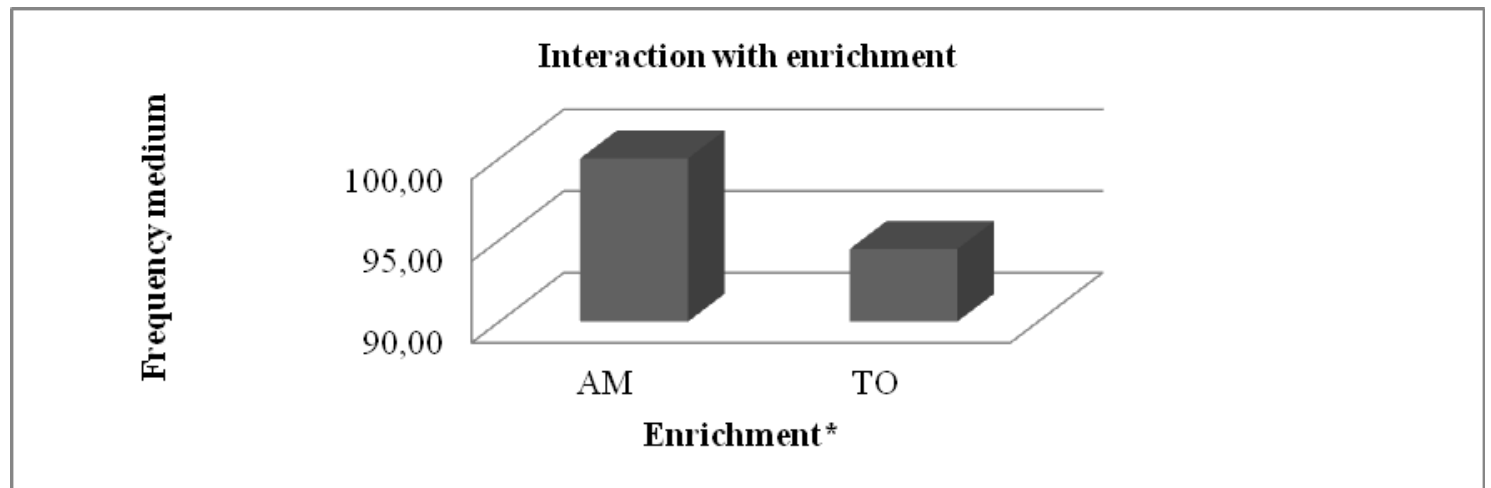

Figure 7. Mean frequency of behavioral category "interaction with environmental enrichment" in adult cockatiels (Nymphicus hollandicus).

*AM- Bead rings, TO - Wooden sticks.

Environmental enrichment should be creative and animal-safe. According to Milatão (2008), enrichment tools must be nontoxic and must not facilitate escape or cause animal harm. Tools should be suitable for each cage and not remain there for long; otherwise they will lose the novelty characteristics. Although the types of enrichment used in the study had not been previously tested, we observed bird interaction with both tools.

When animal behavior is assessed in categories and activity, analyses show different frequencies. The reason is that birds have different behaviors in relation to frequency of activities, despite belonging to the same species. In addition, there is individuality among individuals. Most available indicators of high degree of welfare are found in studies reporting positive animal preferences (Broom et al., 2004).

\section{CONCLUSIONS}

Environmental enrichment showed positive results in some behavioral activities, confirming that birds need an environment that provides more ways to spend their time, thus enhancing welfare. In other activities, it was not possible to observe changes in the behavior of cockatiels in enriched cages. Thus, more research is needed to test other parameters and types of environmental enrichment.

\section{REFERENCES}

ALLGAYER, M.C.; CZIULIK, M. Reprodução de psitacídeos em cativeiro. Rev. Bras. Reprod. Anim., v.31, p.344-350, 2007.

ANDRADE, A.A.; AZEVEDO, C.S. Efeitos do enriquecimento ambiental na diminuição de comportamentos anormais exibidos por papagaios verdadeiros (Amazona aestiva, Psittacidae) cativos. Rev. Bras. Ornitol, v.19, p.56-62, 2011.

ARRUDA, R.; RODRIGUES, D.J.; IZZO, T.J. Rapid assessment of fruit-color selection by birds using artificial fruits at local scale in Central Amazonia. Acta Amaz., v.38, p.291-296, 2008.

BRASIL. Instituto Brasileiro do Meio Ambiente e dos Recursos Naturais Renováveis. Portaria do IBAMA $\mathrm{n}^{\text {o }}$ 93/1998. Available in: $<$ http://www.ibama.gov.br/fauna/legislacao/port_ 93_98.pdf $>$. Accessed in: Feb. 2013.

BROOM, D.M.; MOLENTO, C.F.M. Bem-estar animal: conceito e questões relacionadas revisão. Arch. Vet. Sci,. v.9, p.1-11, 2004.

CASTRO, C.S.S. Pesquisa com primatas e m ambiente natural: técnicas para coleta de dados ecológicos e comportamentais. In: REUNIÃO DA SOCIEDADE BRASILEIRA PARA PROGRESSO DA CIÊNCIA, 62., 2010, Natal, RN. Anais... Natal: UFRN, 2010. 27p. 
CUBAS, Z.S.C.; SILVA, J.C.R.; CATÃO-DIAS, J.L. Tratado de animais selvagens: medicina veterinária. São Paulo: Roca, 2006. 1376p.

DEL-CLARO, K. Comportamento animal: uma introdução à ecologia comportamental. Jundiaí: Livraria Conceito, 2004. 132p.

GORMAN, M. The cockatiel handbook. Hauppauge: Barron's Educational, 2010. 139 p.

KIM, L.C.; GARNER, J.P.; MILLAM, J.R. Preferences of Orange-winged Amazon parrots (Amazona amazonica) for cage enrichment devices. Appl. Anim. Behav. Sci,. v.120, p.216223, 2009.

MEEHAN, C.L., GARNER, J.P., MENCH, J.A., Environmental enrichment and development of cage stereotypy in orange-winged amazon parrots (Amazona amazonica). Dev. Psychobiol., n.44, p.209-218, 2004.

MILITÃO, C. Tratamento de animais em cativeiro, higiene e nutrição animal. [S. 1.: s. n], 2008. (Ficha de Trabalho $\mathrm{n}^{\circ} 5$ ).

PIMENTA, F.R.P. SOARES, A.D.S.; FREITAS, M.L.P. et al. Estudo comportamental de um casal de arara-azul-grande, Anodorhynchus hyacinthinus (Latham, 1790) mantidas em cativeiro no Parque Zoobotânico Vale na Floresta Nacional de Carajás, Pará, Brasil. In: CONGRESSO DE ECOLOGIA DO BRASIL, 9., 2009. Anais... Available in: <http://www.sebecologia.org.br/2009/resumos_ixceb/922.pdf $>$.

Accessed in: Dec 2011.

PRESTES, P.N. Descrição e análise do etograma de Amazona pretrei em cativeiro. Ararajuba, v.8, p.25-42, 2000.
SANTOS, M.S.; SALGADO, A.P.B.; MATTOS, J.F.A.; MONTEIRO, A.R. Influência do enriquecimento ambiental no comportamento de Ara arara una e Ara chloropterus no zoológico vale dos bichos. In: ENCONTRO LATINOAMERICANO DE INICIAÇÃO CIENTÍFICA, 15.; ENCONTRO LATINO AMERICANO DE PÓS-GRADUAÇÃO. 11. [Trabalho apresentado...]. [s.1.]: Universidade do Vale do Parnaiba, 2011. Available in: $<$ http://www.inicepg.univap.br/cd/INIC_2011/an ais/arquivos/0196 0456 01.pdf>. Accessed in: Dec 2011.

SGARBIERO, T. Etograma como ferramenta de avaliação do enriquecimento ambiental para a conservação ex-situ de Ara macao (Linnaeus, 1758) e Ara ararauna (Linnaeus, 1758) no zoológico Municipal de Piracicaba - SP. Sorocaba. 2009. 87f. Trabalho de Conclusão de Curso (Bacharelado em Ciências Biológicas) Universidade Federal de São Carlos, Sorocaba, SP.

SILVA, T.G.G.; VIEIRA, L.N.G.; BARRELLA, W. Estudo preliminar de enriquecimento ambiental no recinto do Tucano-toco (Ramphastos toco). Rev. Eletr. Biol., v.3, p.93104, 2010.

SOARES, A.D.S. et al. Estudo comportamental de um casal de arara - azul - grande, Anodorhynchus hyacinthinus (latham, 1790) mantidas em cativeiro no Parque Zoobotânico Vale na Floresta Nacional de Carajás, Pará, Brasil. In: CONGRESSO DE ECOLOGIA DO BRASIL, 9., São Lourenço, 2009. Anais... São Lourenço: [s. n.], 2009.

YONG, R.J. Environmetal enrichment for captive animals. Oxford: Blackwell Publishing. 2003. 